\title{
Algorithm for assessing forest stand productivity index using leaf area index
}

\author{
Faid Abdul Manan, Muhammad Buce Saleh, I Nengah Surati Jaya, Uus Saepul Mukarom \\ Department of Forest Management, Faculty of Forestry IPB University, Indonesia
}

\begin{tabular}{l} 
Article Info \\
\hline Article history: \\
Received Feb 11, 2019 \\
Revised Jul 2, 2019 \\
Accepted Jul 28, 2019 \\
\hline Keywords: \\
Discriminant analysis \\
Estimator model \\
Forest dimension \\
Forest inventory \\
Hemispherrical photography
\end{tabular}

\begin{abstract}
This paper describes a development of an algorithm for assessing stand productivity by considering the stand variables. Forest stand productivity is one of the crucial information that required to establish the business plan for unit management at the beginning of forest planning activity. The main study objective is to find out the most significant and accurate variable combination to be used for assessing the forest stand productivity, as well as to develop productivity estimation model based on leaf area index. The study found the best stand variable combination in assessing stand productivity were density of poles (X2), volume of commercial tree having diameter at breast height (dbh) 20-40 cm (X16), basal area of commercial tree of dbh $>40 \mathrm{~cm}$ (X20) with Kappa Accuracy of $90.56 \%$ for classifying into 5 stand productivity classes. It was recognized that the examined algorithm provides excellent accuracy of $100 \%$ when the stand productivity was classified into only 3 classes. The best model for assessing the stand productivity index with leaf area index is $\mathrm{y}=0.6214 \mathrm{x}-0.9928$ with $\mathrm{R} 2=0.71$, where $\mathrm{y}$ is productivity index and $\mathrm{x}$ is leaf area index.
\end{abstract}

Copyright $(0) 2019$ Institute of Advanced Engineering and Science. All rights reserved.

\section{Corresponding Author:}

I NengahSurati Jaya,

Department of Forest Management,

Bogor Agricultural University,

Jl. Raya Dramaga, Bogor 16680, West Java, Indonesia.

Email: ins-jaya@apps.ipb.ac.id

\section{INTRODUCTION}

Estimating forest stand productivity with traditional method is a challenging task, since it should be laborious, time consuming and costly. However, implementation of terrestrial forest inventory activities for determining the forest productivity in the field are often constrained by the availability of the human resources, cost and time. Thus, the terrestrial-based method is mostly difficult to be implemented in large area coverage. Many studies [1-13] proven that the variation of the standing stock is affected by its biological and physical factors that may be verified with leaf area index (LAI), density, basal area, volume, biomass, silviculture system, and site quality.

The leaf area index is defined as one side of the leaf from the total area of leaf tissue $\left(\mathrm{m}^{2}\right)$ per unit of land surface area without considering the shape of the leaf $[14,15]$. The leaf area index (LAI) is important for studying the crown structure and it is widely used to describe photosynthesis and transpiration of plant canopy surfaces [16]. LAI also emerged as a key factor in determining the impact of global climate change of forest ecosystem [17] and highly correlated with growth and forest products [18]. The LAI hold a significant role in determining the productivity of forest stands through the role of radiation interception [19]. In addition, LAI is one of the important variables in the functional and physiological models of plants [20], large scale remote sensing models [21], as well as large models ecosystem productivity models [22]. Now, there are several tools have been developed for estimating LAI and assess crown structure with image analysis through light transmittance measurements, one of which is digital hemispherical photography 
(DHP). The use of DHP requires complex image analysis procedures and need a specific software [23-25]. By knowing the LAI, we can assess crown cover conditions and productivity of a forest stand.

Based on the above, the main objective of the study is to identify the determinant factors for assessing the stand productivity using the most consistent and accurate combination of biophysical variables such as stand density, basal area and timber standing stock. The developed discriminant functions would be then used to assess the productivity of the forest stands. The additional study objective is to develop a mathematical model for assessing the productivity class of forest stands using the LAI with DHP technique.

\section{RESEARCH METHOD}

\subsection{Date and Site}

The This study was conducted within the concession area of PT Prabu Alaska, Fakfak District, West Papua Province from January to February 2017. Geographically, the study site is located between $132^{\circ} 43^{\text {' }}$ East longitude \& $133^{\circ} 21^{\prime}$ East longitude and between $2^{\circ} 38^{\prime}$ South latitude \& $3^{\circ} 51^{\prime}$ South latitude. Furthermore, the data processing, analysis and reporting were carried out between May 2017 and February 2018 at the Remote Sensing Laboratory, Faculty of Forestry, IPB.

\subsection{Tools, Software, Hardware and Data}

The tools used on the ground data collection were GPS, suunto, rope, measuring tape, compass, range finder, flagging tape, digital camera, fisheye lens. While, the image data processing hardware used was a set of computer unit with the following software: Hemiview 2.1, Gap Light Analyzer v.2, ArcGIS 10.1, Erdas Imagine 9.1, Excel, and Minitab 17. The primary data used were identification of tree species name, number of trees in each observation plot, stand density, basal area, standing stock volume and hemispherical photos.

\subsection{Research Procedure}

\subsubsection{Vegetation Analysis Data}

Field sampling technique applied in this study was a purposive sampling technique to represent the variation density of a crown cover and stand productivity of forest area. There are also other considerations such as accessibility and locations of plots were in socially allowed areas. In this study, 28 clusters with the size of $50 \mathrm{~m} \times 50 \mathrm{~m}$ square-shaped were chosen purposively, in which each cluster was divided into 56 clusters element with the grid size of $25 \mathrm{~m} \mathrm{x} 25 \mathrm{~m}$. In each of cluster element (plot), there are sub-plot having size of $10 \mathrm{~m} \times 10 \mathrm{~m}$ and $5 \mathrm{~m} \times 5 \mathrm{~m}$. On each plot, all physical variables were measured. The measured variable were diameter breast height (dbh), total tree height, branch tree height, number of individuals, tree species names and GPS coordinate points. All tree with dbh of $\geq 20 \mathrm{~cm}$ was measured in all $25 \mathrm{~m} \mathrm{x} 25 \mathrm{~m}$ size plot, for pole size in $10 \mathrm{~m} \times 10 \mathrm{~m}$, and sapling measured in $5 \mathrm{~m} \times 5 \mathrm{~m}$.

\subsubsection{Capture and Calculation of LAI Data}

DHP point retrieval was performed at observation time in cloudy conditions, ranging from 9am to $4 \mathrm{pm}$. The camera used was Canon EOS D1200 type with $12 \mathrm{mp}$ resolution and hemispherical/fisheye lens Sigma $8 \mathrm{~mm} \mathrm{f} / 3.5$ EX DC. The position of the camera is facing upwards (vertically) and pointing to the north of the compass [16, 26] using hand levelled [26] with height of $1.8 \mathrm{~m}$. Exposure and other settings are automatic from the camera $[25,26]$, after that a new shot is taken. In this research the calculation of LAI from DHP using algorithm software Hemiview 2.1 with threshold method [16].

\subsection{Data Analysis}

\subsubsection{Estimating Indicator of Forest Stand Productivity}

The stand indicator used as forest productivity could describe the condition of the natural forest.

There are three indicators of a sustainable productivity examined, namely: 1) abundance of tree regeneration, 2 ) residual stands and 3) standing stock potential. The indicator variables were stand density, basal area and stand volume. The indicators and their corresponding variables reviewed in this study are summarized in Table 1 with the following details:

1) Individual density in the field $(\mathrm{N})$

Individual density was obtained using the following equation:

$$
\text { Individual density }\left(\mathrm{n} \mathrm{ha}^{-1}\right)=\frac{\text { Total of } \text { individual }}{\text { Plot area }}
$$


2) Basal area (BA)

Basal area was obtained using the following equation:

Basal area $(\mathrm{m} 2 \mathrm{ha}-1)=\frac{\frac{1}{4}\left(\pi(\mathrm{d})^{2}\right)}{\text { Plot area }}$

3) Volume (V)

The volume was calculated using the following formula:

Volume (V) (m3ha-1) = BA. Hbc. F

where:

$\mathrm{V}=$ Volume of trees $(\mathrm{m} 3) ; \mathrm{BA}=$ Basal area $(\mathrm{m} 2) ; \mathrm{D}=$ Diameter of tree at breast height $(\mathrm{m}) ; \mathrm{Hbc}=$ Clearbole tree height (m); $\pi=$ Phi (3.14); $\mathrm{f}=$ the form factor $(0.7)$

The variable indicators in Table 1 are classified into 3 classes (low, moderate, high) and 5 classes (very low, low, moderate, high, very high). Classification is using algorithm complete linkage euclidian distance method. After that, a discriminant analysis function of forest stands productivity index is performed.

Table 1. Forest Productivity Indicator Variables

\begin{tabular}{|c|c|c|}
\hline Indicators & Variables & Code \\
\hline \multirow[t]{11}{*}{ Regeneration } & Sapling density $\left(\mathrm{n} \mathrm{ha}^{-1}\right)$ & $\mathrm{X}_{1}$ \\
\hline & Pole density of the commercial species $\left(\mathrm{n} \mathrm{ha}^{-1}\right)$ & $\mathrm{X}_{2}$ \\
\hline & Pole density of all species ( $\mathrm{n} \mathrm{ha}^{-1}$ ) & $\mathrm{X}_{3}$ \\
\hline & Pole volume of the commercial species $\left(\mathrm{m}^{3} \mathrm{ha}^{-1}\right)$ & $\mathrm{X}_{4}$ \\
\hline & Pole volume of all species $\left(\mathrm{m}^{3} \mathrm{ha}^{-1}\right)$ & $\mathrm{X}_{5}$ \\
\hline & Tree density of the commercial species with $\mathrm{dbh}>20 \mathrm{~cm}\left(\mathrm{n} \mathrm{ha}^{-1}\right)$ & $\mathrm{X}_{6}$ \\
\hline & Tree density of all species diameter $>20 \mathrm{~cm}\left(\mathrm{n} \mathrm{ha}^{-1}\right)$ & $\mathrm{X}_{7}$ \\
\hline & Basal area of the commercial species with $\mathrm{dbh}>20 \mathrm{~cm}\left(\mathrm{~m}^{2} \mathrm{ha}^{-1}\right)$ & $\mathrm{X}_{8}$ \\
\hline & Basal area of all species diameter $>20 \mathrm{~cm}\left(\mathrm{~m}^{2} \mathrm{ha}^{-1}\right)$ & $\mathrm{X}_{9}$ \\
\hline & Tree volume of the commercial species with $\mathrm{dbh}>20 \mathrm{~cm}\left(\mathrm{~m}^{3} \mathrm{ha}^{-1}\right)$ & $\mathrm{X}_{10}$ \\
\hline & Tree volume of all species diameter $>20 \mathrm{~cm}\left(\mathrm{~m}^{3} \mathrm{ha}^{-1}\right)$ & $\mathrm{X}_{11}$ \\
\hline \multirow{6}{*}{$\begin{array}{l}\text { Residual } \\
\text { stand }\end{array}$} & Tree density of the commercial species with dbh $20-40 \mathrm{~cm}\left(\mathrm{n} \mathrm{ha}^{-1}\right)$ & $\mathrm{X}_{12}$ \\
\hline & Tree density of all species diameter $20-40 \mathrm{~cm}\left(\mathrm{n} \mathrm{ha}^{-1}\right)$ & $\mathrm{X}_{13}$ \\
\hline & Basal area of the commercial species with dbh $20-40 \mathrm{~cm}\left(\mathrm{~m}^{2} \mathrm{ha}^{-1}\right)$ & $\mathrm{X}_{14}$ \\
\hline & Basal area of all species diameter $20-40 \mathrm{~cm}\left(\mathrm{~m}^{2} \mathrm{ha}^{-1}\right)$ & $\mathrm{X}_{15}$ \\
\hline & Tree volume of the commercial species with dbh $20-40 \mathrm{~cm}\left(\mathrm{~m}^{3} \mathrm{ha}^{-1}\right)$ & $\mathrm{X}_{16}$ \\
\hline & Tree volume of all species diameter $20-40 \mathrm{~cm}\left(\mathrm{~m}^{3} \mathrm{ha}^{-1}\right)$ & $\mathrm{X}_{17}$ \\
\hline \multirow{6}{*}{$\begin{array}{l}\text { Potential } \\
\text { stock }\end{array}$} & Tree density of the commercial species with $\mathrm{dbh}>40 \mathrm{~cm}\left(\mathrm{n} \mathrm{ha}^{-1}\right)$ & $\mathrm{X}_{18}$ \\
\hline & Tree density of all species diameter $>40 \mathrm{~cm}\left(\mathrm{n} \mathrm{ha}^{-1}\right)$ & $\mathrm{X}_{19}$ \\
\hline & Basal area of the commercial species with $\mathrm{dbh}>40 \mathrm{~cm}\left(\mathrm{~m}^{2} \mathrm{ha}-1\right)$ & $\mathrm{X}_{20}$ \\
\hline & Basal area of all species with $>40 \mathrm{~cm}\left(\mathrm{~m}^{2} \mathrm{ha}^{-1}\right)$ & $\mathrm{X}_{21}$ \\
\hline & Tree volume of the commercial species $\mathrm{dbh}>40 \mathrm{~cm}\left(\mathrm{~m}^{3} \mathrm{ha}^{-1}\right)$ & $\mathrm{X}_{22}$ \\
\hline & Tree volume of all species with dbh $>40 \mathrm{~cm}\left(\mathrm{~m}^{3} \mathrm{ha}^{-1}\right)$ & $\mathrm{X}_{23}$ \\
\hline
\end{tabular}

\subsubsection{Data Evaluation}

Prior to any further analysis, the data was evaluated descriptively by considering the data normality and outlier of the sample data measured in the field. Basic statistical analysis was done to obtain the mean, standard deviation and coefficient of variance $(\mathrm{CV})$ values and then used to create indicator classes for estimating forest stand productivity. The multicollinearity test was also done to fulfill the statistical rules on discriminant analysis as well as to see the relationship between independent variables. The level of closeness of the relationship between the independent variables was calculated using the Pearson correlation coefficient.

\subsubsection{Discriminant Functions Analysis}

In this study, the discriminant function of forest stand productivity was the forward method, where the variables are entered firstly, secondly, thirdly etc. Then, this discriminant method simultaneously identifies the sequence of variables entered.

\subsubsection{Classification, Accuracy Assessment and Model Selection}

The best model selection is done with accuracy test. The best key indicators and models are determined based on the model with the highest accuracy of all the set variables used. The accuracy assessment method used a confusion matrix, particularly to calculate the overall accuracy (OA) and Kappa 
Accuracy (KA) [28]. Model selection was done by performing significance test that expresses the significant difference between the Kappa accuracy of each model. These test results were then used to select the best model. If the difference between models has a value of $\mathrm{z}>1.96$, then this means that the model differs significantly, otherwise is similar.

\subsubsection{Model Development of Productivity Index with LAI}

The forest stand productivity index was constructed using combination from the selected variable model (as Y variable) associated with leaf area index (as variable $\mathrm{X}$ ) using regression analysis. Mathematically, the equation of puncture index function of forest stand productivity is presented as follows:

$$
\mathrm{PI}=f(\mathrm{LAI})
$$

where: $\mathrm{PI}=$ productivity index; $f(\mathrm{LAI})=$ function of leaf area index

\section{RESULTS AND ANALYSIS}

\subsection{Density, Basal Area, Volume}

The density variable values were derived from the sample plots measured in the field, expressed as the number of trees per unit area, while the basal area and volume values were derived from the measured tree diameter at breast height ( $\mathrm{dbh}$ ) per unit area. The average of tree density ranging from 31.43 to 123.14 tree ha ${ }^{-1}\left(\mathrm{X}_{6}, \mathrm{X}_{7}, \mathrm{X}_{12}, \mathrm{X}_{13}, \mathrm{X}_{18}, \mathrm{X}_{19}\right)$, while the average tree basal area is about $0.05 \pm 0.03 \mathrm{~m}^{2} \mathrm{ha}^{-1}\left(\mathrm{X}_{9}\right)$ which is the basal area of all species in $\mathrm{dbh}>20 \mathrm{~cm}$. The average tree volume in the dryland natural forest area of Papua around $0.48 \pm 0.40 \mathrm{~m}^{3} \mathrm{ha}^{-1}\left(\mathrm{X}_{11}\right)$ which is the volume of all species in $\mathrm{dbh}>20 \mathrm{~cm}$ (Table 2).

The result of coefficient of variance $(\mathrm{CV})$ calculation on tree density data ranged from 44.39$86.81 \%$, tree basal area ranged between 53.70-89.11\%, tree volume ranged between 69.91-117.51\%. This means that tree density, basal area and volume data has a high variation. It also matches with a statement that the structure of forest stands in Papua has a high diversity [7, 29]. In addition, the average basal area and volume showed a regular pattern based on diameter class. The value of basal area and volume tend to follow the diameter class. The higher the diameter class has the higher value of basal area and volume. The highest basal area and volume value were found in the $>40 \mathrm{~cm}$ diameter class ranging from 0.03 $\pm 0.02 \mathrm{~m}^{2} \mathrm{ha}^{-1}\left(\mathrm{X}_{21}\right)$ and $0.30 \pm 0.34 \mathrm{~m}^{3} \mathrm{ha}^{-1}\left(\mathrm{X}_{23}\right)$ for volume. The lowest basal area and volume size were found in the $20-40 \mathrm{~cm}$ diameter class ranging from $0.02 \pm 0.01 \mathrm{~m}^{2} \mathrm{ha}^{-1}\left(\mathrm{X}_{15}\right)$ for basal area and $0.18 \pm 0.12$ $\mathrm{m}^{3} \mathrm{ha}^{-1}\left(\mathrm{X}_{17}\right)$ for volume. Meanwhile, the average tree density decreased by its diameter class. The highest density of trees in the $20-40 \mathrm{~cm}$ diameter class was $88.86 \pm 45.86$ trees ha ${ }^{-1}\left(\mathrm{X}_{13}\right)$ and the lowest in the $>40$ $\mathrm{cm}$ diameter class by $33.71 \pm 27.41$ trees $\mathrm{ha}^{-1}\left(\mathrm{X}_{19}\right)$. The stand structure forms an inverted $\mathrm{J}$ (Figure 1) indicating normal growth conditions in a normal natural forest but has an inverted bell shape in a planted forest, that forest conditions indicated that future forest stands will be safe [1-6, 29-31].

Table 2. Average Mean of Forest Productivity Variables in Study Site

\begin{tabular}{cccccccc}
\hline Variable & Mean & Std & CV $(\%)$ & Variable & Mean & Std & CV $(\%)$ \\
\hline $\mathrm{X}_{1}$ & 1992.86 & 631.26 & 31.68 & $\mathrm{X}_{13}$ & 88.86 & 45.86 & 51.61 \\
$\mathrm{X}_{2}$ & 391.07 & 190.00 & 48.58 & $\mathrm{X}_{14}$ & 0.02 & 0.01 & 56.99 \\
$\mathrm{X}_{3}$ & 453.57 & 194.44 & 42.87 & $\mathrm{X}_{15}$ & 0.02 & 0.01 & 53.70 \\
$\mathrm{X}_{4}$ & 73.83 & 39.37 & 53.32 & $\mathrm{X}_{16}$ & 0.16 & 0.12 & 76.23 \\
$\mathrm{X}_{5}$ & 88.13 & 40.69 & 46.17 & $\mathrm{X}_{17}$ & 0.18 & 0.12 & 69.91 \\
$\mathrm{X}_{6}$ & 110.86 & 54.82 & 49.45 & $\mathrm{X}_{18}$ & 31.43 & 27.28 & 86.81 \\
$\mathrm{X}_{7}$ & 123.14 & 54.66 & 44.39 & $\mathrm{X}_{19}$ & 33.71 & 27.41 & 81.29 \\
$\mathrm{X}_{8}$ & 0.05 & 0.03 & 60.47 & $\mathrm{X}_{20}$ & 0.03 & 0.02 & 89.11 \\
$\mathrm{X}_{9}$ & 0.05 & 0.03 & 54.27 & $\mathrm{X}_{21}$ & 0.03 & 0.02 & 85.23 \\
$\mathrm{X}_{10}$ & 0.45 & 0.41 & 91.56 & $\mathrm{X}_{22}$ & 0.29 & 0.34 & 117.51 \\
$\mathrm{X}_{11}$ & 0.48 & 0.40 & 84.41 & $\mathrm{X}_{23}$ & 0.30 & 0.34 & 113.25 \\
$\mathrm{X}_{12}$ & 78.29 & 42.68 & 54.52 & & & & \\
\hline
\end{tabular}

Another factor affecting the tree density, basal area and volume is the type of tree species [1-6, 10-12]. The tree species found in dryland natural forests of Papua were matoa (Pometia pinnata), ketapang (Terminalia catappa), batu (Pterygota horsfiledii), ketaran (Koordensiodendron pinnatum), pala hutan (Horsfieldia irya), binuang (Octomeles sumatrana), merbau (Intsia bijuga), and other types (Figure 2). These tree species are the dominant species in dryland tropical rain forest in Papua [5, 7, 29]. 


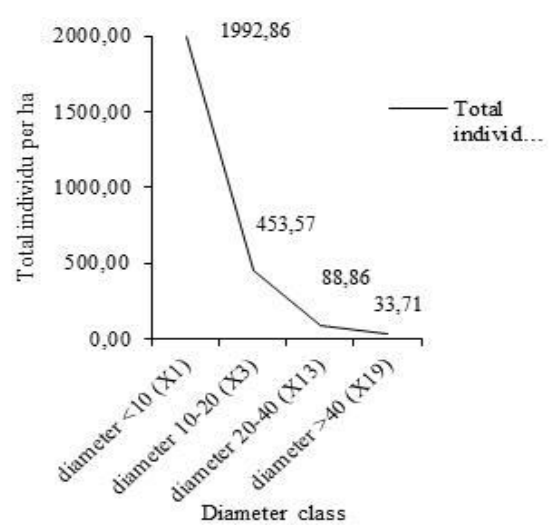

Figure 1. The stand structure based on diameter class

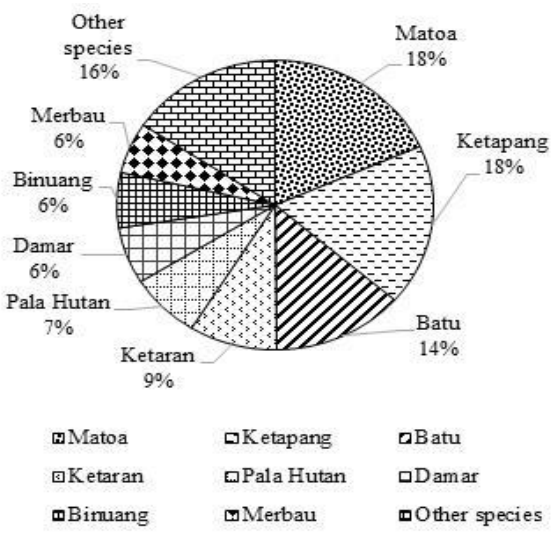

Figure 2. The proportion of dominant tree species in study site

\subsection{Determining Indicator Variables for Estimating Forest Stand Productivity Index}

The classification and determining of forest productivity indicator in natural forest of Papua begins with conducting multicollinearity test by looking at the correlation between variable $\mathrm{X}$. This test is used in determining indicator of forest productivity. The result of correlation matrix obtained informs to select 11 variables from 23 initial variables that will be used as a combination variable to estimate the indicator of forest productivity in Papua (Table 3 ). The selected variables are sapling density $\left(\mathrm{X}_{1}\right)$, pole density $\left(\mathrm{X}_{2}\right)$, tree density $>20 \mathrm{~cm}\left(\mathrm{X}_{6}\right)$, basal area $>20 \mathrm{~cm}\left(\mathrm{X}_{8}\right), \mathrm{V}>20 \mathrm{~cm}\left(\mathrm{X}_{10}\right)$, tree density $20-40 \mathrm{~cm}\left(\mathrm{X}_{12}\right)$, basal area $20-40 \mathrm{~cm}\left(\mathrm{X}_{14}\right), \mathrm{V} 20-40 \mathrm{~cm}\left(\mathrm{X}_{16}\right)$, tree density $>40 \mathrm{~cm}\left(\mathrm{X}_{18}\right)$, basal area $>40 \mathrm{~cm}\left(\mathrm{X}_{20}\right)$, and V $>40 \mathrm{~cm}\left(\mathrm{X}_{22}\right)$. The combination of these variables then arranged to form 2, 3, 4, and 5 variable combination with 3 and 5 classes of forest stand productivity. This classification was aimed to obtain the most accurate model with simpler variables, that could be applied with cheaper cost and easily implemented in the field.

Table 3. The best 3 Combinations using One to Five Independent Variables to Classify 3 and 5 Classes of Forest Productivity with Complete Linkage Dendrogram and Standardize Euclidian Distance

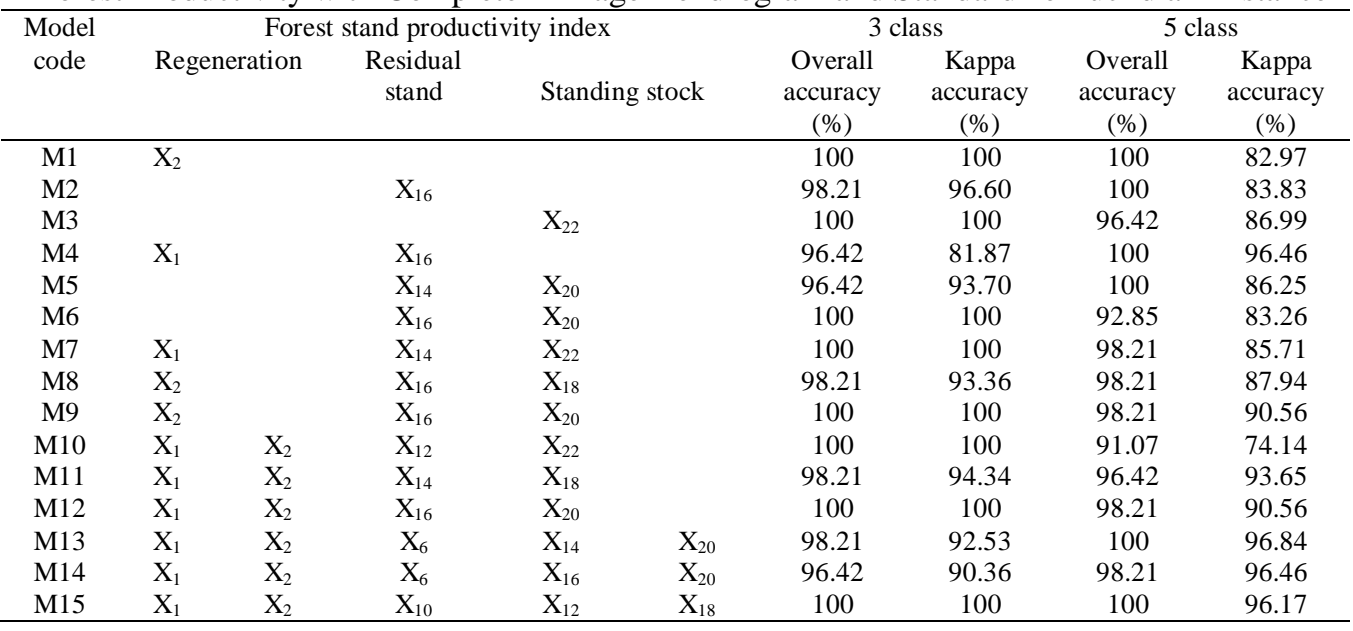

\subsection{Discriminant Function and Productivity Index Accuracy Test}

The study found that the overall accuracy obtained from the classification of forest stand productivity with 3 classes and 5 classes are more than $90 \%$. It was also shown that stand productivity is strongly influenced by stand variables such as regeneration stock (sapling and pole density), residual stand (density, basal area and volume dbh $20-40 \mathrm{~cm}$ ) also standing stock (density, basal area and volume dbh $>40 \mathrm{~cm})$. The most consistent and accurate indicators were used as determinants of the productivity of dryland natural forest stands i.e. pole density $\left(\mathrm{X}_{2}\right)$, volume $\mathrm{dbh} 20-40 \mathrm{~cm}\left(\mathrm{X}_{16}\right)$, and basal area $\mathrm{dbh}>40 \mathrm{~cm}\left(\mathrm{X}_{20}\right)$ (Table 3). 
The accuracies provided by each five variables combination in assessing stand producitivity is summarized in Table 3. Even with five productivity classes, the accurate productivity assessment was obtained, providing accuracy of more than $85 \%$. The single variable using individual density indicator of pole $\left(\mathrm{X}_{2}\right)$, dbh $20-40 \mathrm{~cm}\left(\mathrm{X}_{16}\right)$ and volume $\mathrm{dbh}>40 \mathrm{~cm}\left(\mathrm{X}_{22}\right)$ provide high kappa accuracy value in classifying 3 classes stand productivity, i.e., $100 \%$, $97 \%$ and $100 \%$, respectively.

When classifying 5 classes of stand productivity, the study show that 3 variables are consistently needed, namely regeneration stock, residual stand, and stand potential. This can be seen in the 3, 4 and 5 variables combinations, based on the test of significance to the accuracy value of the combination model, the combination of 3,4 and 5 variables did not differ significantly where the $\mathrm{z}$-test shows the $\mathrm{z}$-value is $<1.96$. Then, it preferable to select or apply the model with high accuracy and fewer variables. The selected combination that could be used as a forest stand productivity index is the combination no. 9 (M9) with perfect accuracy of $100 \%$. The discriminant function of the 3 classes productivity for combinations of individual pole density variables $\left(\mathrm{X}_{2}\right)$, volume $\mathrm{dbh} 20-40 \mathrm{~cm}\left(\mathrm{X}_{16}\right)$ and basal area $\mathrm{dbh}>40 \mathrm{~cm}\left(\mathrm{X}_{20}\right)$ are presented respectively in Table 4 . Productivity class $\mathrm{I}$ has a medium $\mathrm{X}_{2}$ value, low $\mathrm{X}_{16}$ and $\mathrm{X}_{20}$ value. Productivity class II has a high $\mathrm{X}_{2}$ value, moderate $\mathrm{X}_{16}$ and $\mathrm{X}_{20}$ value. While, productivity class III has a low value of $\mathrm{X}_{2}$, and high $\mathrm{X}_{16}$ and $\mathrm{X} 20$ value.

Table 4. Discriminant Function for Classifying Forest Productivity using Variables $\mathrm{X}_{2}, \mathrm{X}_{16}$ and $\mathrm{X}_{20}$

\begin{tabular}{cc}
\hline Forest Productivity Class & Discriminant Function \\
\hline I & $\mathrm{Y}=-5.274+0.022 \mathrm{X}_{2}+0.002 \mathrm{X}_{16}+0.081 \mathrm{X}_{20}$ \\
II & $\mathrm{Y}=-33.175+0.0556 \mathrm{X}_{2}+0.006 \mathrm{X}_{16}+0.237 \mathrm{X}_{20}$ \\
III & $\mathrm{Y}=-15.392-0.0058 \mathrm{X}_{2}+0.016 \mathrm{X}_{16}+0.479 \mathrm{X}_{20}$ \\
\hline \multicolumn{2}{l}{ Remarks: I Low productivity; II Medium productivity; III High productivity }
\end{tabular}

\subsection{Model Relationship Productivity Index with LAI}

As discussed above, the combination no. 9 (M9) would be the best combination of variables for assessing the 3 classes stand productivity having 100\% overall accuracy and kappa accuracy. Based on the best variable regression test, the correlation between forest stand productivity index and leaf area index follow the linear model with the equation $y=0.6214 x-0.9928$ with $\mathrm{R}^{2}=0.71$ (Figure 3 ). The pattern of relation between 3 classes of forest stand productivity index with leaf area index shows linear model, it means that the increase of stand productivity value is influenced by the meeting of the vertical structure of the stand at the observation location. The leaf area index affects the density, basal area and stand volume per unit area. An increase in leaf area index will affect the standing productivity class in general. Thus, the forest stand productivity class could be predicted by using the leaf area index instead of using the traditional stand variables such as basal area, stand density and regeneration. The use of LAI variable might reduce the volume field measurement since the ground LAI could be measured simply by using hemispherical camera.

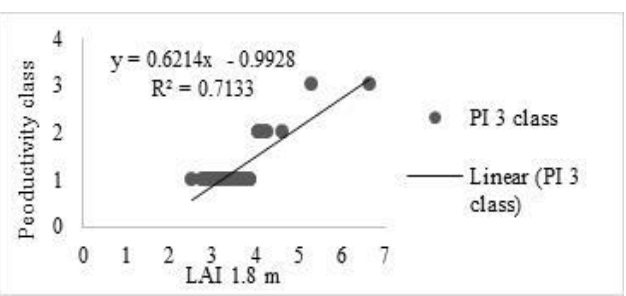

(a)

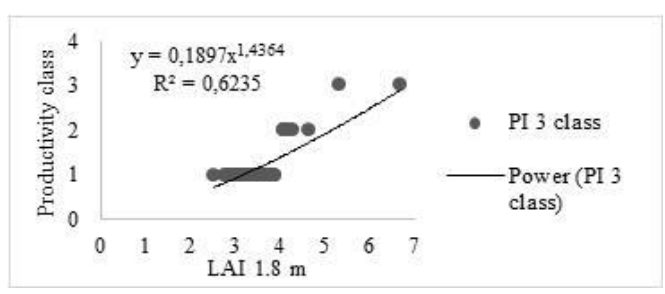

(c)

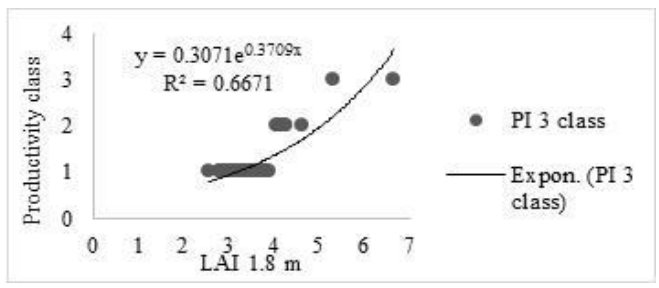

(b)

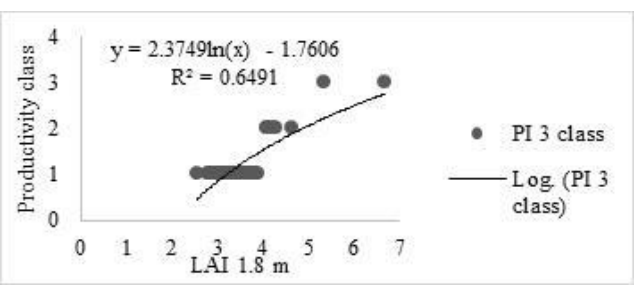

(d)

Figure 3. Regression analysis result of forest productivity index with leaf area index a. linear; b. exponential; c. power; d. logarithmic 


\subsection{Leaf Area Index Value}

LAI in our research was obtained from hemispherical photographs by using the threshold method in hemiview canopy analysis software. Each one plot represented by a hemispherical photograph which is then analyzed into one LAI value. Thus, in this study we have 56 LAI values which grouped based on stands productivity class in natural forest. Once grouped, we describe a range of LAI values on productivity class. Our research results indicate that there are 3 classes of productivity in study site i.e. productivity class I, productivity class II, and productivity class III. LAI interval of productivity class I is $2.5-3.8$, productivity class II vary between 4.0-4.6, and productivity class III between 5.3 to 6.6. This range value showed minimum and maximum range of LAI values forming fairly open to very dense canopy on 3 productivity class in study site. These results can be used to monitor vegetation conditions based on the value of LAI in dryland natural forest of West Papua. Other studies indicate LAI value on broadleaf forest is 4.4-8.8 [22] and global averages from ground measurements of tropical evergreen broadleaf forests around 4.9 [32]. Furthermore, another study shows that the in situ measurements for LAI in evergreen broadleaf forest in East Africa vary between 3.95 to 7.4 [29] and in Amazonian evergreen broadleaf forest between 3.25 and 5.1 [34]. While LAI value in the agroforestry system vary between 1.0-5.3 [16].

Several factors are contributed to LAI value variations in productivity class. The factors closely related to leaf area, tree population density, and tree dimension (basal area, volume). Studies [6], [26] also explained that the increase in plant populations will increase the value of LAI. At the leaf level, these include influences associated with variation in leaf pigments, leaf internal structure, saturation, and the orientation of the leaf relative to solar radiation $[21,25]$. Afterwards, heterogeneity in tree height, diameter and the size of tree gaps influences reflectance and light transmittance at the multi tree scale $[6,21,35]$.

\section{CONCLUSION}

From the foregoing analysis and discussion, the study conclude that the most consistent and accurate indicators used as determinants of stand productivity of dryland forest stands are pole density $\left(\mathrm{X}_{2}\right)$, volume commercial tree dbh $20-40 \mathrm{~cm}\left(\mathrm{X}_{16}\right)$, basal area commercial tree $\mathrm{dbh}>40 \mathrm{~cm}\left(\mathrm{X}_{20}\right)$. Algorithm of complete linkage with standardize Euclidian distance can be used to create a classification of productivity index. It is also concluded that the relationship between forest stand productivity index and leaf area index follow the linear model with the equation $\mathrm{y}=0.6214 \mathrm{x}-0.9928$ with $\mathrm{R}^{2}$ of 0.71 . The study also indicates that productivity variables vary in West Papua with the value of coefficient of variance $(\mathrm{CV})$ calculation on tree density data ranged between $51.61-81.29 \%$, tree basal area ranged between $52.82-87.88 \%$, and tree volume ranged from $69.91-113.60 \%$. Beside the above, LAI value in study site is between 2.5-6.6. Based on the results obtained, it is also concluded that the use of DHP at a height of $1.8 \mathrm{~m}$ could be used for estimating the productivity based on the LAI value, particularly in natural forest. The researchers suggest development of other models using DHP Techniques at some height in different ecosystem types.

\section{ACKNOWLEDGEMENTS}

The authors would like to extend highly appreciation to the project manager of the collaboration between the Faculty of Forestry, Bogor Agricultural University and Prabu Alaska Co. Limited for the financial support during the ground data collection in the field and data processing. Sincerely thanks are also extended to the anonymous reviewer for constructive comments and inputs on the original draft of the manuscript.

\section{REFERENCES}

[1] Muhdin, Suhendang E, Wahjono D, Purnomo H, Istomo, Simangunsong B. The variability of stand structure of logged-over natural forest. J Manajemen Hutan Tropika. 2008; 14(2): 81-87.

[2] Pan Y, Birdsey RA, Phillips O, Jackson RB. The structure, distribution, and biomass of the world's forests. Annual Review of Ecology Evolution and Systematics. 2013; 593-622.

[3] Gyamfi A, Swaine EK, Adam KA, Pinard M, Swaine MD. Can harvesting for timber in tropical forest enhance timber tree regeneration?. Forest Ecology and Management. 2014; 314. $26-37$.

[4] Laurans M, Herault B, Vieilledent G, Vincent G. Vertical stratification reduces competition for light in dense tropical forests. Forest Ecology and Management. 2014; 329: 79-88.

[5] Whitfeld T, Lasky J, Damas K, Sosanika G, Molem K, Montgomery R. Species richness, forest structure, and functional diversity during succession in the New Guinea lowlands. Biotropica. 2014; 46(5).

[6] Lefsky MA, Hudak AT, Cohen WB, Acker SA. Pattern of covariance between forest stand and canopy structure in the Pasific Northwest. Remote Sensing of Environment. 2005; 95: 517-531

[7] Kuswandi R, Murdjoko A. Population structures of four tree species in logged-over tropical forest in South Papua, Indonesia: an integral projection model approach. Indonesian Journal of Forestry Research. 2015; 2: 93-101. 
[8] Murdjoko A, Marsono D, Sadono R, Hadisusanto S. Population dynamics of pometia for the period of postselective logging in tropical rainforest, Southern Papua, Indonesia. Biosaintifika: Journal of Biology \& Biology Education. 2016; 8.

[9] Wahyuni S, Jaya INS, Puspaningsih N. Model for estimating above ground biomass of reclamation forest using unmanned aerial vehicles. Indonesian Journal of Electrical Engineering and Computer Science. 2016; 4(3): 586593.

[10] Wahyuni NI, Kafiar Y. Species composition and structure of secondary forest at Nunuka, North Bolaang Mangondow. Jurnal Wasian. 2017; 4(1): 27-36.

[11] Ibanez T, Keppel G, Baider C, Birkinshaw C, Culmsee H, Cordell S, Florens F, Franklin J, Giardina C, Gillespie T, Laidlaw M, Litton C, Martin T, Ostertag R, Parthasarathy N, Randrianaivo R, Randrianjanahary M, Rajkumar M, Rasingam L, Birnbaum P. Regional forcing explains local species diversity and turnover on tropical islands. Global Ecology and Biogeography. 2018. doi:10.1111/geb.12712.

[12] Vincent J, Turner B, Alok C, Novotny V, Weiblen DG, Whitfeld T. Tropical forest dynamics in unstable terrain: a case study from New Guinea. Journal of Tropical Ecology. 2018; 1-19.

[13] Kardika AJ, Jaya INS, Puspaningsih N, Mulia F. Growth-site quality assesment of nypa fruticans using unmanned aerial vehicles images: a case study in Kubu Raya Regency, West Kalimantan Proivnce. Indonesian Journal of Electrical Engineering and Computer Science. 2018; 9(2): 502-511.

[14] Breda NJJ. Ground based measurement of leaf area index: a review of methods, instruments and current controversies. J Exp. Bot. 2003; 54(392): 2403-2417.

[15] Smith ML, Anderson J, Fladeland M. Field measurement for forest carbon monitoring. Forest Canopy Struct. Prop. 2008; 15: 179-196.

[16] Khairiah RN, Setiawan Y, Prasetyo LB, Prita AP. Leaf area index in different type of agroforestry systems based on hemispherical photographs in Cidanau Watershed. IOP Conf. Series: Earth and Environmental Science. Bogor, West Java. 2017; 54.

[17] Thomas, Sean C, Winner WE. Leaf area index of an old growth Douglas-fir forest estimated from direct structural measurement in the canopy. Can. J For. Res. 2000; 30: 1922-1930.

[18] Fownes JH, Harrington RA. Modelling growth and optimal rotations of tropical multipurpose trees using unit leaf rate and leaf area index. 1990; J Appl. Ecol. 27: 886-896.

[19] Jarvis PG, Leverenz JW. Productivity of temperate, deciduos and evergreen forests. Encyclopedia of Plant Physiology. 1983; 12D: 234-280.

[20] Fuentes S, Palmer AR, Taylor D, Zeppel M, Whitley R, Eamus D. An automated procedure for estimating the leaf area index (LAI) of woodland ecosystem using digital imaginery, Matlab programming and its aplication to an examination of the relationship between remotely sensed and field measurement of LAI. Func. Plant. Biol. 2008; 35:1070-1079.

[21] Tang H, Dubayah R, Brolly M, Ganguly S, Zhang G. Large-scale retrieval of leaf area index and vertical foliage profile from the spaceborne waveform lidar (GLAS/ICEsat). Remote Sensing of Environment. 2014; 154: 8-18.

[22] Turner D, Cohen W, Kennedy R, Fassnacht K, Briggs J. Relationships between leaf area index and Landsat TM spectral vegetation indices across three temperate zone sites. Remote Sensing of Environment. 1999; 70: 52-68.

[23] Chianucci F. A note on estimating canopy cover from digital cover and hemispherical photography. Silva Fennica. $2015 ; 50$

[24] Jarcuska B, Kucbel S, Jaloviar P. Comparison of output from two programmes for hemispherical image analysis: Gap Light Analyser and WinScanopy. J For. Sci. 2010; 56: 147-153.

[25] Promis A, Gartner S, Butler-Manning D, Duran-Rangel C, Reif A, Cruz G, Hernandez L. Comparison of four different programs for the analysis of hemispherical photographs using parameters of canopy structure and solar radiation transmittance. Waldokol Online. 2011; 11: 19-33.

[26] Liu J, Pattey E, Admiral S. Assesment of in situ crop LAI measurement using undirectional view digital photography. Agric. For. Meteorol. 2013; 169: 25-34.

[27] Origo N, Calders K, Nightingale J, Disney M. Influence of levelling technique on the retrieval of canopy structural parameters from digital hemispherical photography. Agric. For. Meteorol. 2017; 237-238: 143-149.

[28] Jaya INS, Kobayashi S. Classification of detailed forest cover types based upon the separability algorithm: a case study in the Yahiko Mountain and Shibata Forest Area. Journal of The Remote Sensing Society of Japan. 1995; 15(1): 40-53.

[29] Kuswandi R, Sadono R, Supriyatno N, Marsono D. Diversity of stand structure in logged-over forest based on Papua biogeography. J Manusia \& Lingkungan. 2015; 22(2): 151-159.

[30] Kusmana C, Susanti S. Species composition and stand structure of natural forest in hutan pendidikan gunung walat, Sukabumi. Jurnal Silvikultur Tropika. 2016; 6(3).

[31] Susanty FH, Suhendang E, Jaya INS, Kusmana C. Performance of dipterocarps forest base on stand structure model approach. Jurnal Penelitian Hutan Tanaman. 2013; 10(4): 185-199.

[32] Wang Y, Ian Y, Zhang Y, El-Saleous N, Knyazikhin Y, Vermote E, Myneni RB. Investigation of product accuracy as a function of input and model uncertainties: Case study with SeaWiFS and MODIS LAI/FPAR algorithm. Remote Sensing of Environment. 2001; 78: 299-313.

[33] Aragao LEOC, Shimabukuro YE, Espirito-Santo FDB, Williams M. Spatial validation of the collection 4 MODIS LAI product in eastern Amazonia. IEEE Trans. Geosci. Remote Sens. 2005; 43: 2526-2534.

[34] Kraus T. Ground-Based Validation of the MODIS Leaf Area Index Product for East African Rain Forest Ecosystems. PhD Thesis. Erlangen: Universität Erlangen-Nürnberg Germany. 2008. 
[35] Easter MJ, Spies TA. Using hemispherical photography for estimating photosynthetic photon flux density under canopies and in gaps in Douglas-fir forests of th Pasific Northwest. Can. J. For. Res. 1994; 24: 2050-2058.

\section{BIOGRAPHIES OF AUTHORS}

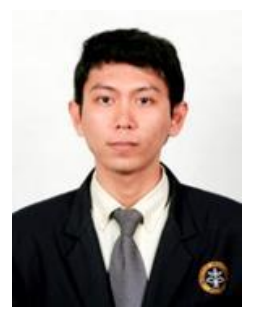

Faid Abdul Manan is a graduate student of Forest Management Science, Graduate School of IPB University. His research interest is in remote sensing and hemispherical photography to support forest planning activity. He got his bachelor degree of forestry in 2012 from Forest Resources Conservation and Ecotourism Department, Faculty of Forestry, IPB University.

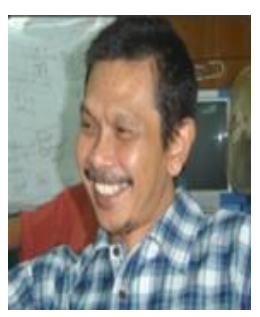

Dr. M. Buce Saleh is a permanent associate professor at the Forest Management Department, Faculty of Forestry, IPB University. His special interest is in the field of remote sensing and geomatics in forest management. He got his PhD in 2002 from Niigata University, Master of Sciences in 1988 from Graduate School of Bandung Institute of Technology and bachelor of forestry in 1981 from Forest Management Department, Faculty of Forestry IPB university.

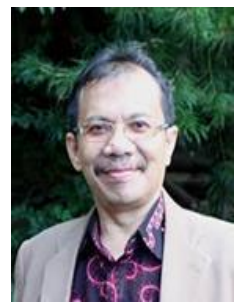

Prof. Dr. I Nengah Surati Jaya is a permanent professor of forest planning since 2007 at IPB University, majoring in remote sensing and spatial geoscience. Since 1990, he has numerous researches, publications and works related to the remote sensing and spatial modelling in the forestry and environmental related sectors. Recently, his research has been focused on the applied science on the use high resolution images, terrestrial data and fisheye camera to develop practical method as well as algorithm to support a sustained forest management. He got his $\mathrm{PhD}$ in 1996 from Niigata University, Master's degree in 1993 from Graduate School of Environmental Science, Niigata University, bachelor's of forestry in 1985 from Forest Management Department, Faculty of Forestry, IPB University.

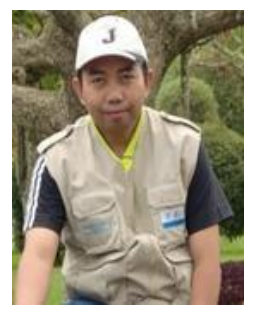

Uus Saepul Mukarom is a laboratory staff at Remote Sensing and GIS Laboratory of Forest Management Department, IPB University. His works interest is in remote sensing and spatial geoscience to support forest planning activity. He got his bachelor degree of forestry in 2013 from Faculty of Forestry, Nusa Bangsa University. 